
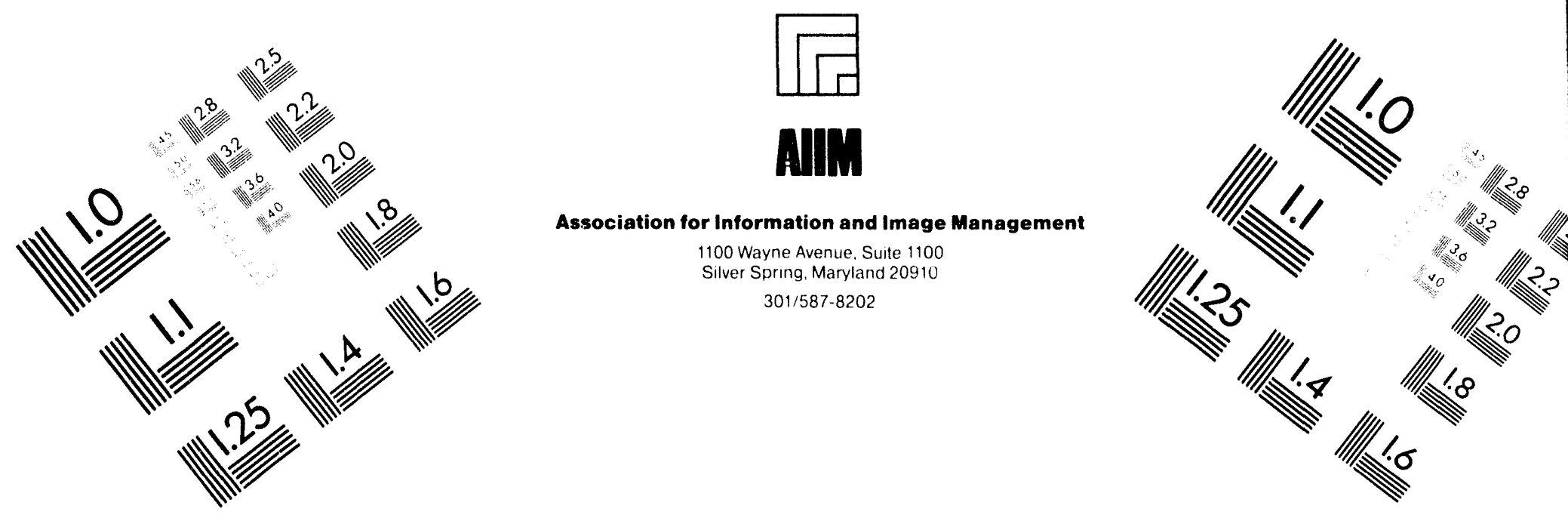

\title{
Centimeter
}

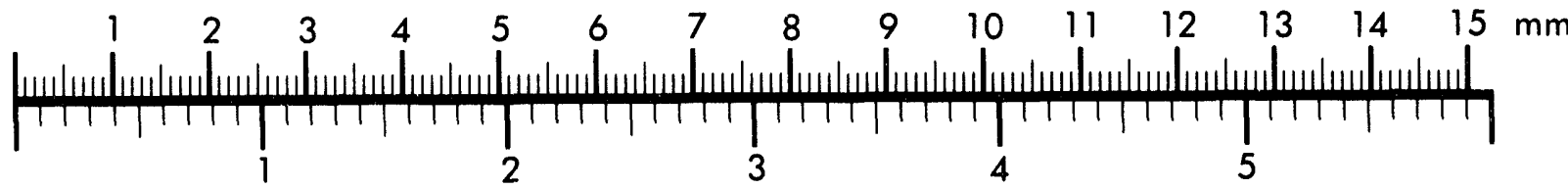

Inches
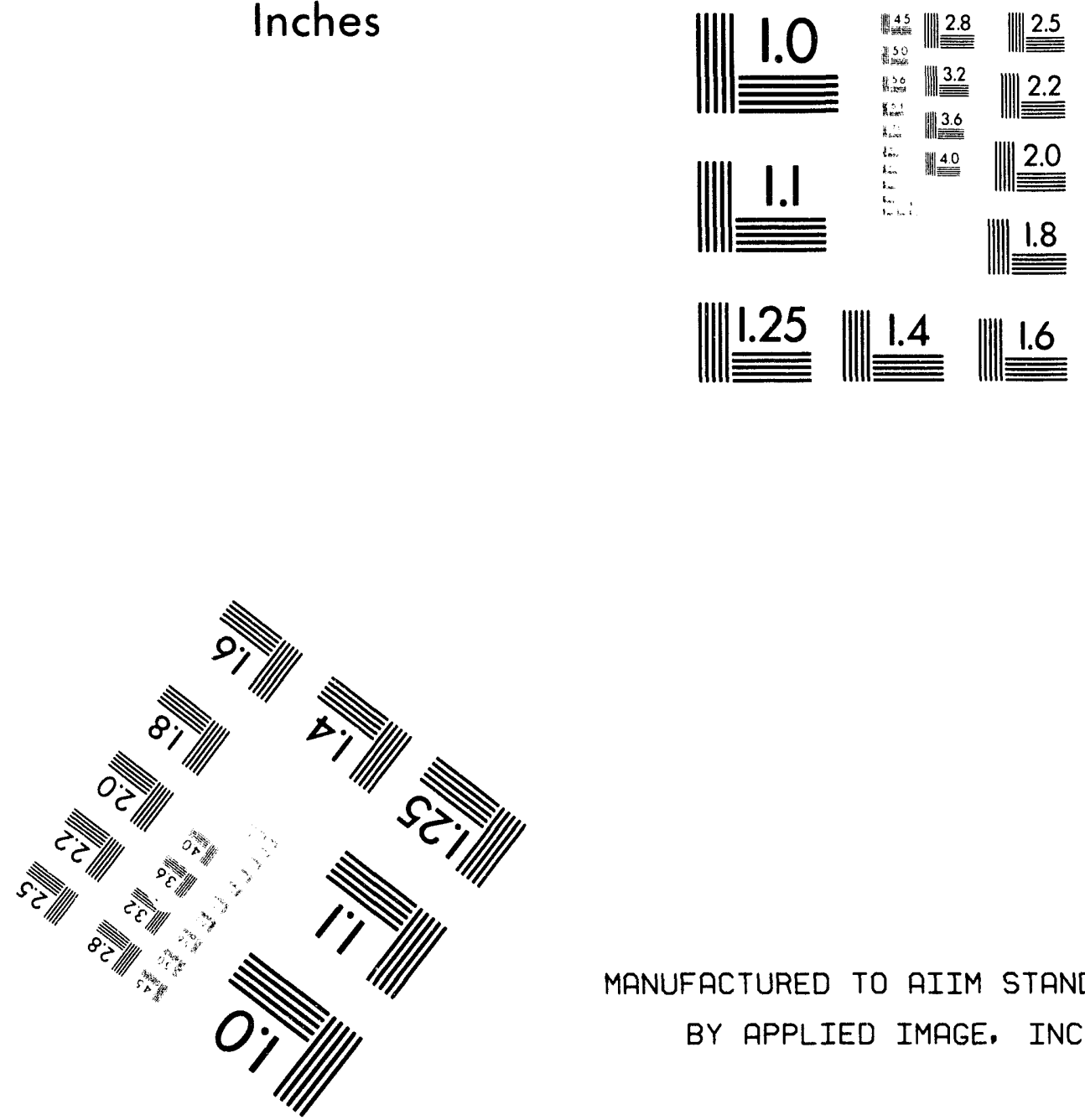

MANUFACTURED TO AIIM STANDARDS

BY APPLIED IMAGE. INC.

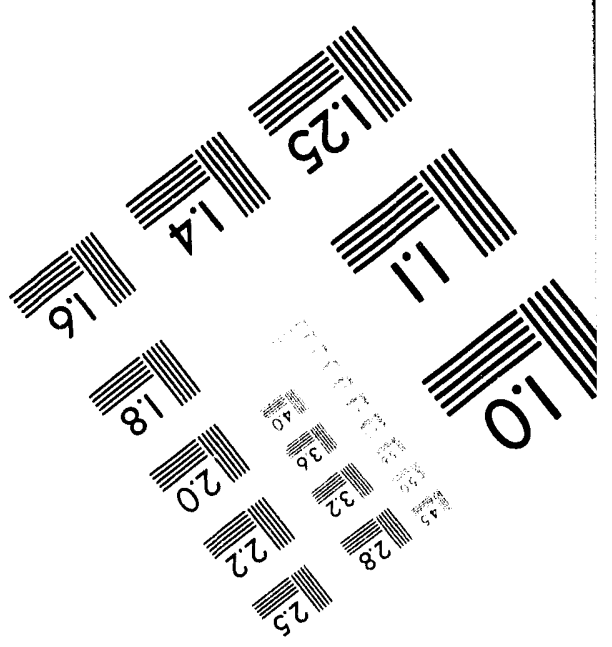



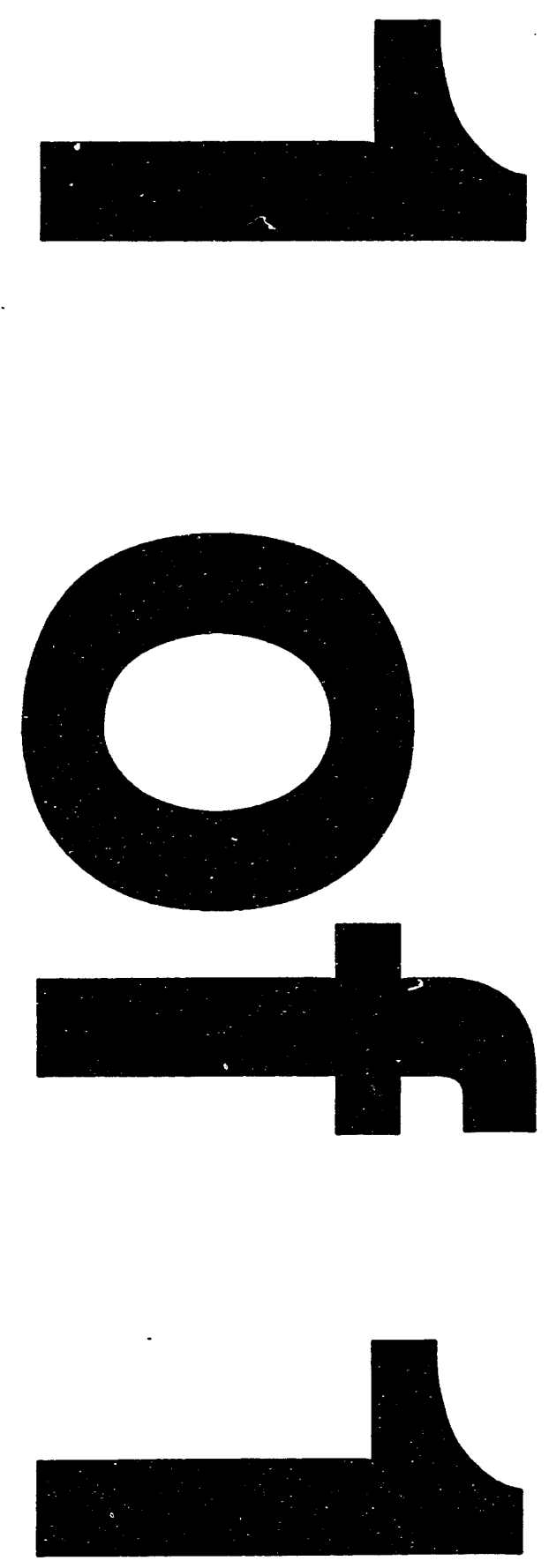


\section{A STATION BLACKOUT SIMULATION FOR THE ADVANCED NEUTRON SOURCE REACTOR USING THE INTEGRATED PRIMARY AND SECONDARY SYSTEM MODEL}

Erich A. Schneider

*Cornell University, Ithaca, NY 14853.

Prepared by

OAK RIDGE NATIONAL LABORATORY

managed by

MARTIN MARIETTA ENERGY SYSTEMS, INC.

for the

U.S. DEPARTMENT OF ENERGY under contract DE-AC05-84OR21400 


\section{CONTENTS}

LIST OF FIGURES $\ldots \ldots \ldots \ldots \ldots \ldots \ldots \ldots \ldots \ldots \ldots \ldots \ldots \ldots$ ACKNOWLEDGMENTS $\ldots \ldots \ldots \ldots \ldots \ldots \ldots \ldots \ldots \ldots \ldots \ldots \ldots \ldots \ldots \ldots$ ABSTRACT $\ldots \ldots \ldots \ldots \ldots \ldots \ldots \ldots \ldots \ldots \ldots \ldots \ldots \ldots \ldots \ldots \ldots \ldots \ldots$

1. INTRODUCTION $\ldots \ldots \ldots \ldots \ldots \ldots \ldots \ldots \ldots \ldots \ldots \ldots \ldots \ldots \ldots$

2. MODEL DESCRIPTION $\ldots \ldots \ldots \ldots \ldots \ldots \ldots \ldots \ldots \ldots \ldots \ldots \ldots$

3. RESULTS AND DISCUSSION $\ldots \ldots \ldots \ldots \ldots \ldots \ldots \ldots \ldots \ldots \ldots \ldots$

3.1 CASE A: WITHOUT BATTERIES $\ldots \ldots \ldots \ldots \ldots \ldots \ldots \ldots \ldots \ldots$

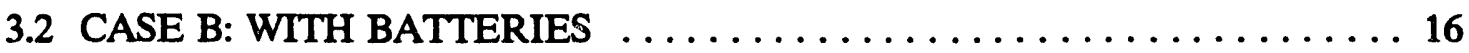

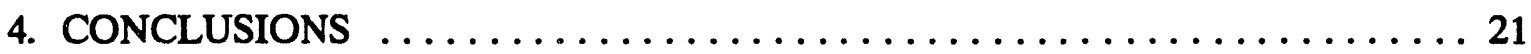

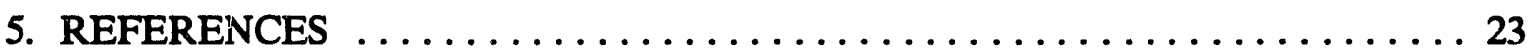

Appendix A. REFLECTOR VESSEL COOLING SYSTEM $\ldots \ldots \ldots \ldots \ldots \ldots$

Appendix B. PROPORTIONAL.INTEGRAL-DIFFERENTIAL CONTROL . . . . 29 


\section{LIST OF FIGURES}

Figure $\quad$ Page

1 Advanced Neutron Source reactor secondary cooling system-node diagram . . 4

2 Pump speed vs time $\ldots \ldots \ldots \ldots \ldots \ldots \ldots \ldots \ldots \ldots \ldots \ldots$

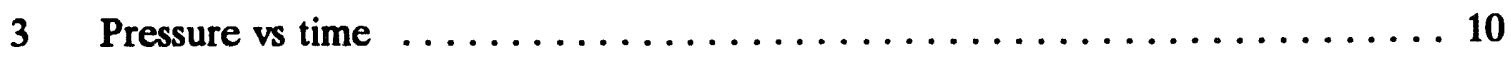

4 Mass flow rate vs time $\ldots \ldots \ldots \ldots \ldots \ldots \ldots \ldots \ldots \ldots \ldots \ldots \ldots \ldots$

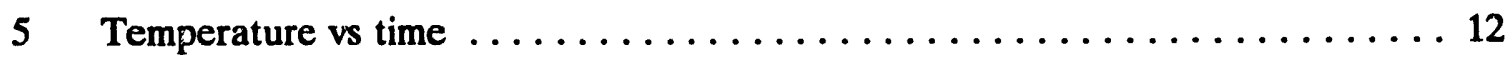

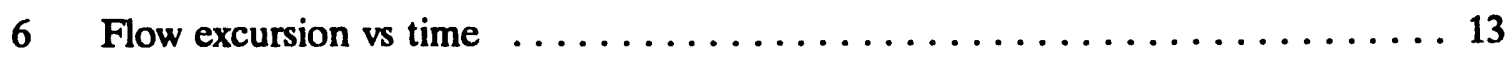

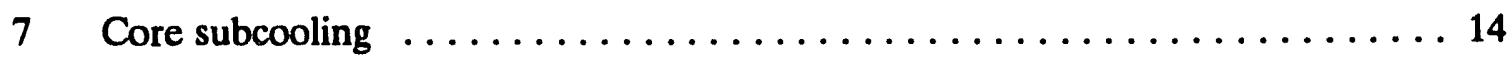

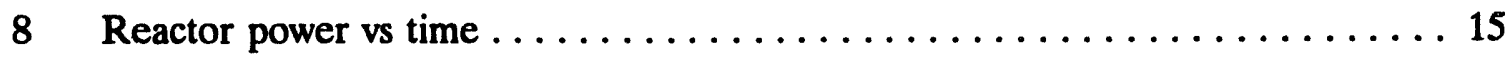

9 Advanced Neutron Source reactor reflector vessel cooling system-node diagram $\ldots \ldots \ldots \ldots \ldots \ldots \ldots \ldots \ldots \ldots \ldots \ldots \ldots$ 


\section{ACKNOWLEDGMENTS}

I would like to thank my advisor, Norbert Chen, for his invaluable guidance and encouragement during all stages of my work here. I would also like to thank Grady Yoder and Mark Wendel for their reviews and comments regarding this paper. Also, thanks to George McNutt for his help in deciphering the Advanced Neutron Source reactor blueprints and to the entire Thermal Systems Technology Section Staff for their assistance throughout the semester. 


\begin{abstract}
The Advanced Neutron Source Reactor (ANSR) is a research reactor to be built at Oak Ridge National Laboratory. This paper deals with thermal-hydraulic analysis of ANSR's cooling systems during nominal and transient conditions, with the major effort focusing upon the construction and testing of computer models of the reactor's primary, secondary and reflector vessel cooling systems. The code RELAP5 was used to simulate transients, such as loss of coolant accidents and loss of off-site power, as well as to model the behavior of the reactor in steady state. Three stages are involved in constructing and using a RELAP5 model: (1) construction and encodiñ of the desired model, (2) testing and adjustment of the model until a satisfactory steady state is achieved, and (3) running actual transients using the steady-state results obtained earlier as initial conditions. By use of the ANSR design specifications, a model of the reactor's primary and secondary cooling systems has been constructed to run a transient simulating a loss of off-site power. This incident assumes a pump coastdown in both the primary and secondary loops. The results determine whether the reactor can survive the transition from forced convection to natural circulation.
\end{abstract}




\section{INTRODUCTION}

The Advanced Neutron Source Reactor (ANSR) is a research reactor characterized by a high heat flux, a high mass flux, and a high degree of subcooling at the core inlet. It will produce a high intensity neutron flux for applications ranging from basic physical research to materials analysis and nuclear medicine research. ${ }^{1,2}$

Presently at the advanced conceptual design stage, ANSR features an upflow to facilitate natural circulation after shutdown, a submerged piping system to prevent loss of coolant and air ingestion into the primary system, and a nitrogen-charged accumulator to lessen depressurization in the event of pipe breaks. To meet safety requirements, a conceptual safety analysis report ${ }^{2}$ (CSAR) has been completed. The accident scenarios discussed in this report include primary system pipe breaks at various key locations with several mitigation options, various station blackout events, and reactivity insertion accidents as the initial event. For the analyses of these scenarios, the computer code RELAP5 ${ }^{3}$ was used. RELAP5 is a one-dimensional, two-phase, transient code developed by the Idaho National Engineering Laboratory for this type of analysis.

The purpose of this report is to develop a more realistic representation of the reactor secondary cooling system (RSCS), including a thermal siphon simulation, to enhance the capability of the existing ANSR system model and to study flow excursion margin behavior by performing a station blackout transient with and without battery-powered pony motors.

A model of the reactor primary cooling system (RPCS) has been operational for some time; it was desired to implement detailed models of the RSCS and the reflector vessel cooling system (RVCS). See Appendix A for a discussion of the RVCS. After the RSCS model was developed, implemented, and tested, a station blackout ${ }^{4}$ test case was analyzed using the integrated primary and secondary system model. (A description of the RPCS RELAP5 model can be found elsewhere, ${ }^{5}$ so only the RSCS model is discussed here.) 


\section{MODEL DESCRIPTION}

The purpose of RSCS is to remove the heat generated from the core and convected by the primary cooling system. This removal is accomplished by means of a horizontal U-tube type heat exchanger-the heavy water in the shell side of the RPCS never comes into contact with the light water in the tube side of the RSCS. Water that has passed through the heat exchanger on the secondary side is subsequently passed through a mechanical-draft cooling tower, where air driven by fans is used to cool the water. The heat is thus rejected to the ultimate sink-the atmosphere. Cooled water is then returned to the reactor heat-sink cooling pool until it goes through the cycle again.

In order to construct the model, it was necessary to obtain detailed layout information on RSCS, including pipe lengths and diameters, locations of junctions and $90^{\circ}$ bends, volumes of storage pools, and specifications for the pump and heat exchanger. These were obtained from three sources: the ANSR system design descriptions ${ }^{6,7}$ (SDDs), ANSR blueprints, ${ }^{8}$ and personal interviews with the ANS design engineering staff. The final model is shown in Fig. 1 and a brief description of the model's characteristics follows.

The RSCS consists of four identical loops-three of which are active under normal operating conditions. Each loop thus removes one-third of the heat load carried by the RPCS. This heat is then rejected to the ultimate sink by evaporation within the cooling towers. For the cooling tower, a simplified model is employed-a mass source (time-dependent volume 301) is linked by a controlled mass-flow junction (time-dependent junction 302) to a pipe that functions as a heat exchanger with the secondary loop (pipe 303). Flow then proceeds through a junction (single junction 304) to a sink (time-dependent volume 305). For model testing purposes, mass flow through this system is controlled using the proportional-integral-differential (PID) method (see Appendix B), to ensure that the temperature in the secondary loop corresponds with operating specifications.

When the pump is operational and forced convection is taking place, flow in the hot leg of the secondary loop proceeds from the heat exchanger (pipe 201) to the hot leg riser (branch 204). Under normal operating conditions, valve 207 is open, and valves 205 and 220 are closed, thus disabling the natural circulation loop. The flow then proceeds underground through concrete piping (pipe 210) to the cooling tower (pipe 212). The cooling tower is fixed at atmospheric pressure by time-dependent volume 228 . The coolant returns to the reactor building, again by means of underground piping (pipe 214), and is deposited into the top of the reactor heat sink cooling pool (pipe 218). This pool has a volume of $1680 \mathrm{~m}^{3}$-large enough to ensure an adequate inventory of cool water if a power outage or similar incident disables the forced convection loop through the cooling tower. The surface of the pool is also fixed at atmospheric pressure (by time-dependent volume 230).

The secondary coolant pump (pump 223) draws water through a pipe (branch 222) from the bottom of the pool and is located at the highest point in the RSCS loop. This pump is rated at $1.7 \mathrm{~m}^{3} / \mathrm{s}(26,235 \mathrm{gal} / \mathrm{min})$ and $27.4 \mathrm{~m}(90 \mathrm{ft})$ head. Additional data were not available, so other pump characteristics were scaled from the available data for the main coolant pump.

The RSCS is also endowed with a natural circulation loop that is capable of removing sufficient heat from the priniary side to ensure safe operation after reactor shutdown. This loop is enabled when the pressure at the secondary pump outlet drops below a 


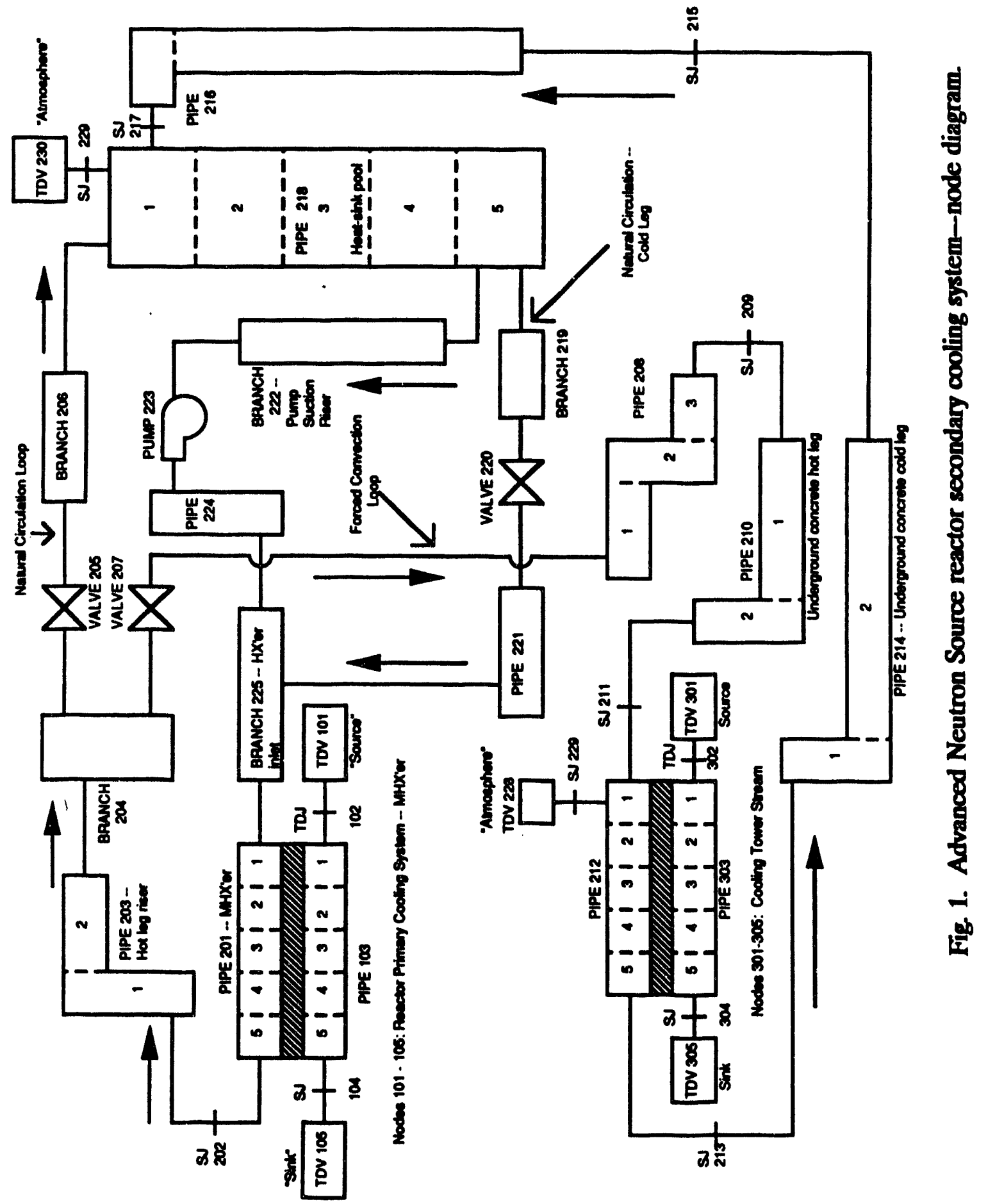


critical value (assumed to be $20 \%$ below nomina' until more definitive numbers are available). As this low pressure reading is an indication of a rupture in the piping or a loss of pump head, the forced convection loop is disabled. To accomplish this, motor valves 205 and 220 are opened, and valve 207 is closed (to prevent backflow from the cooling tower). The resultant natural convection loop draws cool water from the bottom of the pool, passes it through the heat exchanger, and deposits the heated water in the top of the pool. The pool's thermal inertia is large enough that operation under these conditions should be safe for hours, if necessary.

After the steady state was established and the RSCS code was integrated into the RPCS model, it was decided to use the new model to simulate an accident. The event to be simulated was a loss of off-site power, an anticipated event at $99.9 \%$ probability level. This incident terminates the operation of all pumps within the RPCS and RSCS. It was desired to determine whether the reactor could survive without the presence of battery-driven pony motors that maintain the primary coolant pumps operating at $10 \%$ capacity (i.e., whether the pony motors were necessary to ensure that no core damage occurs). 


\section{RESULTS AND DISC.USSION}

\subsection{CASE A: WTTHOUT BATTERIES}

For the case without pony motors, all seven pumps (three main coolant, three secondary coolant, and one makeup) were allowed to coast down from their steady-state values to zero based upon the RELAP5 torque-inertia equation. The loss of power occurs at time $\mathrm{t}=0 \mathrm{~s}$ (see Table 1). By $2.16 \mathrm{~s}$, the Monte Carlo pumps (MCPs) have coasted down to one-half speed (see Fig. 2). During the first few tenths of a second of the transient, the pump coastdown is accompanied by a decrease in the pressure at the core inlet (from 3.2 to $2.0 \mathrm{MPa}$ in $2.32 \mathrm{~s}$; see Fig. 3). This decrease in pressure results, in part, from the sudden loss of pump head that accompanies pump coastdown. This decrease may also be attributed to the loss of coolant inventory. Makeup water, which is injected into the system, ceases at $t=0.84 \mathrm{~s}$, while letdown flow, which is drawn from the system, decreases more gradually in response to depressurization, only ceasing at $t=25 \mathrm{~s}$. Thus, the letdown flow continues to draw off a few kilograms per second of water even after the makeup ceases to replace an equal amount. The pressure drop over the core, which was 1.6 MPa under nominal conditions, decreases to $1.0 \mathrm{MPa}$ after $0.8 \mathrm{~s}$. A smaller pressure drop over the core signifies a smaller mass flow and, indeed, the total core flow (Fig. 4) decreases from $1994 \mathrm{~kg} / \mathrm{s}$ in the steady state to $1580 \mathrm{~kg} / \mathrm{s} 0.8 \mathrm{~s}$ into the transient. Throughout this time, the reactor operates at its maximum power of $344 \mathrm{MW}$; therefore, the core exit temperature (Fig. 5) of the coolant increases $5 \mathrm{~K}$, from 358 to $363 \mathrm{~K}$. This coolant increase occurs because the coolant water picks up more heat per unit mass as it passes through the core as a result of the decreasing core flow.

These conditions bring about a situation that exceeds one of the criteria for reactor scram-exceeding the power-to-flow ratio. The normalized power-to-flow ratio, which is defined to equal 1.0 under nominal conditions, exceeds 1.15 (i.e., the flow has decreased by a significant amount). This situation occurs at $0.61 \mathrm{~s}$. However, to simulate inevitable delay time in the flow sensor, control rod insertion does not begin until $200 \mathrm{~ms}$ later (at $0.81 \mathrm{~s}$ ). It is at this point, just before reactor power begins to decrease, that the first Costa flow excursion' (FE) ratio minimum occurs (see Fig. 6). These minima represent points where the reactor comes nearest to failure. If the ratio remains above one, there is no danger of an FE taking place. This ratio is calculated as follows:

$$
F E \text { ratio }=\frac{7.8125 \times 10^{4} \cdot \sqrt{V_{f}} \cdot T_{\text {mbcool }}}{q_{\text {hotapor }}},
$$

where

$\mathrm{q}_{\text {loupot }}=$ local heat flux at the exit of the lower core $\left(\mathrm{W} / \mathrm{m}^{2}\right)$,

$V_{\mathbf{f}}=$ liquid velocity at lower core exit $(\mathrm{m} / \mathrm{s})$,

$\mathrm{T}_{\text {subcool }}=$ subcooling at lower core exit $(\mathrm{K})$. 
Table 1. Events timeline-station blackout without pony motors

\begin{tabular}{|c|c|}
\hline $\begin{array}{c}\text { Time } \\
(s)\end{array}$ & Event \\
\hline 0.00 & $\begin{array}{l}\text { Beginning of transient; loss of external power; coastdown of primary, secondary, } \\
\text { and makeup pumps }\end{array}$ \\
\hline 0.63 & $\begin{array}{l}\text { Power/flow ratio of } 1.2 \text { (the nominal value of } 1.15+5 \% \text { for uncertainties and } \\
\text { set-point drift) exceeded; reactor scram signal sent }\end{array}$ \\
\hline 0.66 & Makeup flow reaches zero on check valve closure \\
\hline 0.83 & Control rod insertion (scram stroke) begins \\
\hline 0.90 & $\begin{array}{l}\text { First flow excursion minimum, } 1.77 \text {, reached as a result of decreasing core flow and } \\
\text { initial depressurization }\end{array}$ \\
\hline 0.92 & Hot stripe bulk temperature reaches maximum of $437 \mathrm{~K} ;$ subcooling $=32 \mathrm{~K}$ \\
\hline 1.27 & $\begin{array}{l}\text { Pressure at secondary pump outlet drops to set point (assumed to be } 20 \% \text { below } \\
\text { nominal); natural circulation valves in secondary loops open and forced } \\
\text { convection valve closes }\end{array}$ \\
\hline 1.32 & Hot stripe bulk temperature reaches minimum of $333 \mathrm{~K}$; subcooling $=139 \mathrm{~K}$ \\
\hline 1.50 & Accumulator outflow peaks at $20 \mathrm{~kg} / \mathrm{s}$ \\
\hline 2.16 & Monte Carlo pumps at $50 \%$ speed \\
\hline 6.36 & Pressure at hot leg riser drops to $15 \%$ below nominal \\
\hline 15 & Letdown system isolated by valves \\
\hline 22.50 & Monte Carlo pumps coast down to zero \\
\hline 27.60 & Flow excursion ratio falls below 1 as a result of Monte Carlo pump coastdown \\
\hline 28.50 & Bulk temperature in hot stripe reaches saturation \\
\hline 28.98 & Transient terminated by overheating in lower core hot stripe \\
\hline
\end{tabular}

The first minimum occurs at $0.84 \mathrm{~s}$ and has a value of 1.78 . As can be seen from the above formula, it was reached as a result of a decreasing core flow (which causes $V_{\text {core }}$ to decrease) combined with a constant high heat flux. Indeed, subcooling (Fig. 7) at the hottest spot within the core falls to $33 \mathrm{~K}$, and subcooled film boiling is taking place along the walls in the hot channel. As soon as the control rods are inserted, however, the reactor drops within $0.5 \mathrm{~s}$ to decay heat level ( $\sim 15 \mathrm{MW}$; see Fig. 8). This causes the heat flux in the core to decrease, which results in a sudden rise in the FE ratio-by $2.0 \mathrm{~s}$, it has risen to 75. A corresponding drop may be seen in the core exit temperature; during the same time, it falls from 363 to $326 \mathrm{~K}$.

As the system's pressure decreases, it triggers a passive response-the gas bubbles at the top of the accumulators begin to expand because of the lowered pressure, which pushes water from the accumulators into the system. As shown the graphs, by $2 \mathrm{~s}$, injection from the accumulators outpaces loss to the letdown system. This inflow slows the system pressure drop and lessens the rate of decrease of the pressure at the core outlet. The accumulators thus perform their duty by maintaining system water inventory and preventing a more dramatic pressure drop-it is not until $5.58 \mathrm{~s}$ that the pressure at the outlet of the hot leg riser falls to $15 \%$ below its nominal value. 


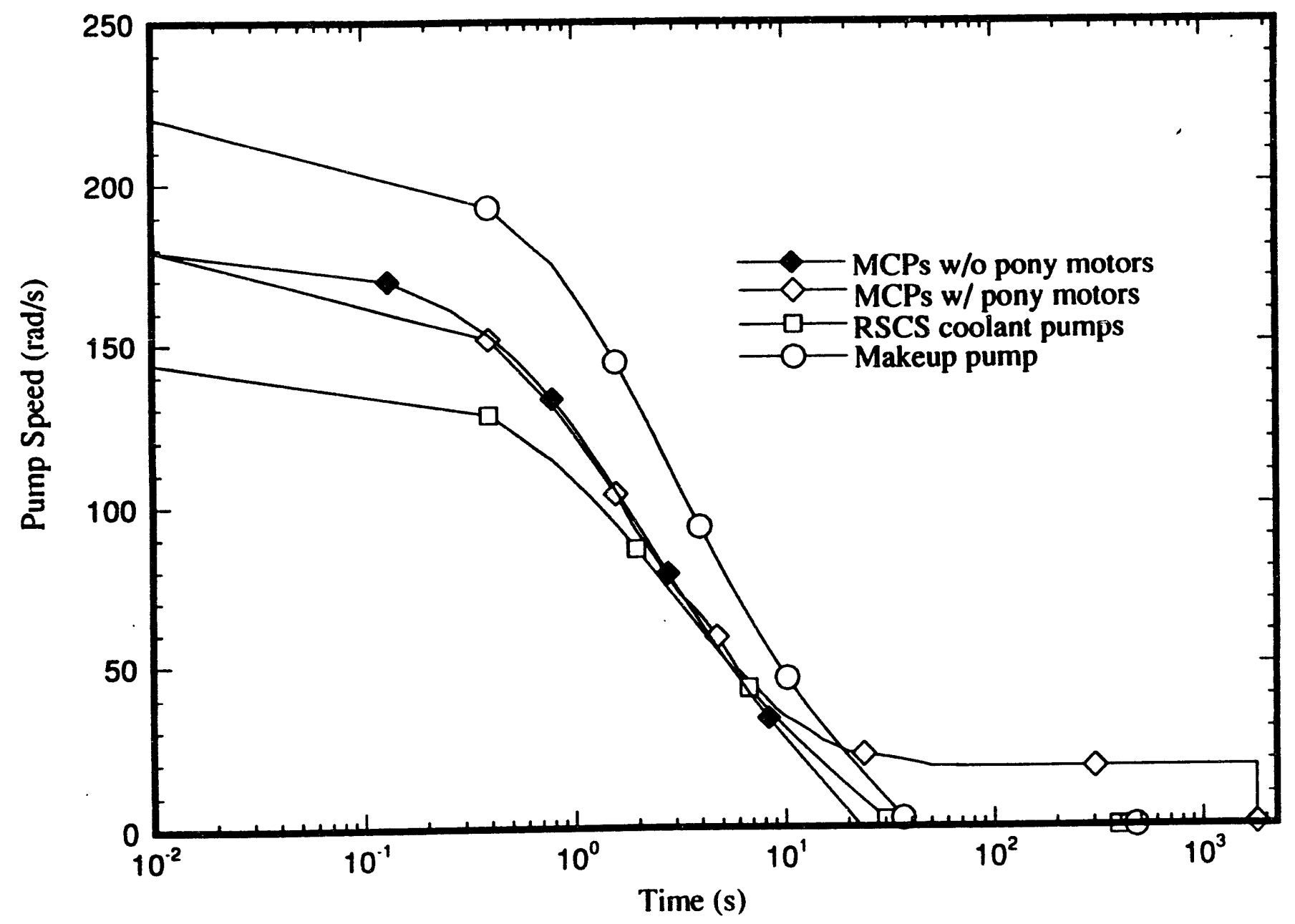

0

Fig. 2. Pump speed vs time. (MCPs = Monte Carlo pumps, and RSCS = reactor secondary cooling system.) 


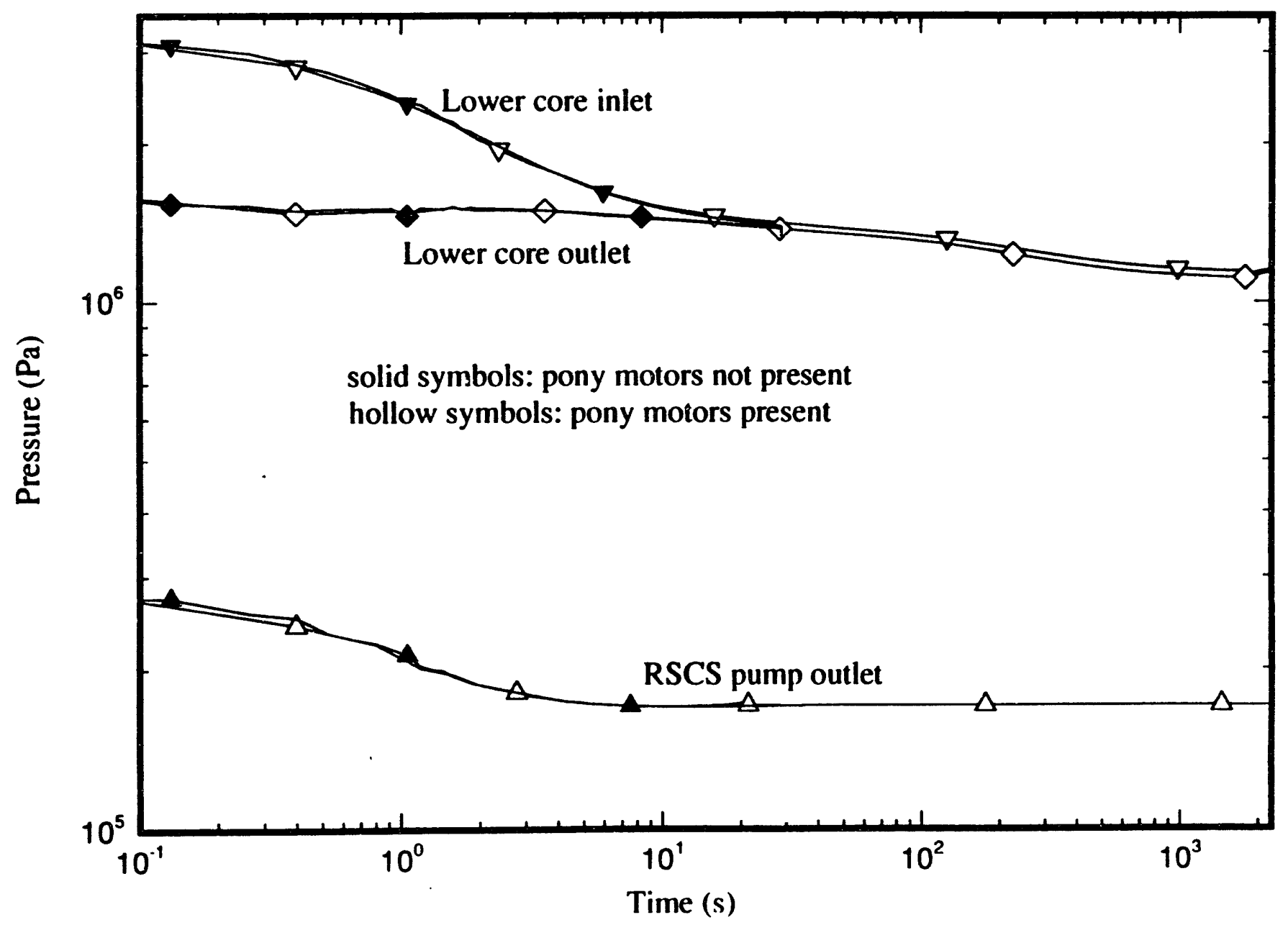

Fig. 3. Pressure vs time. (RSCS = reactor secondary cooling system.) 


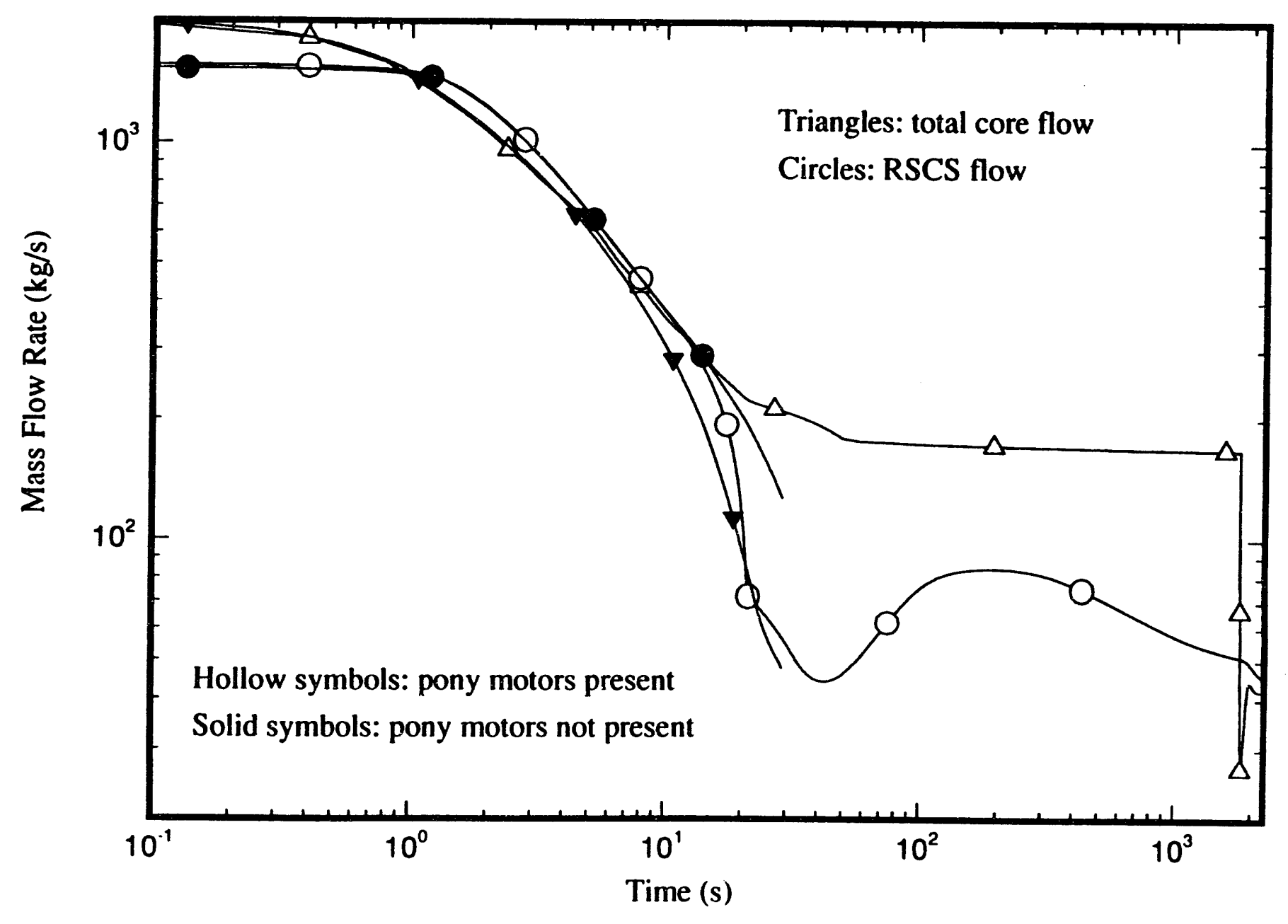

Fig. 4. Mass flow rate vs time. (RSCS = reactor secondary cooling system.) 


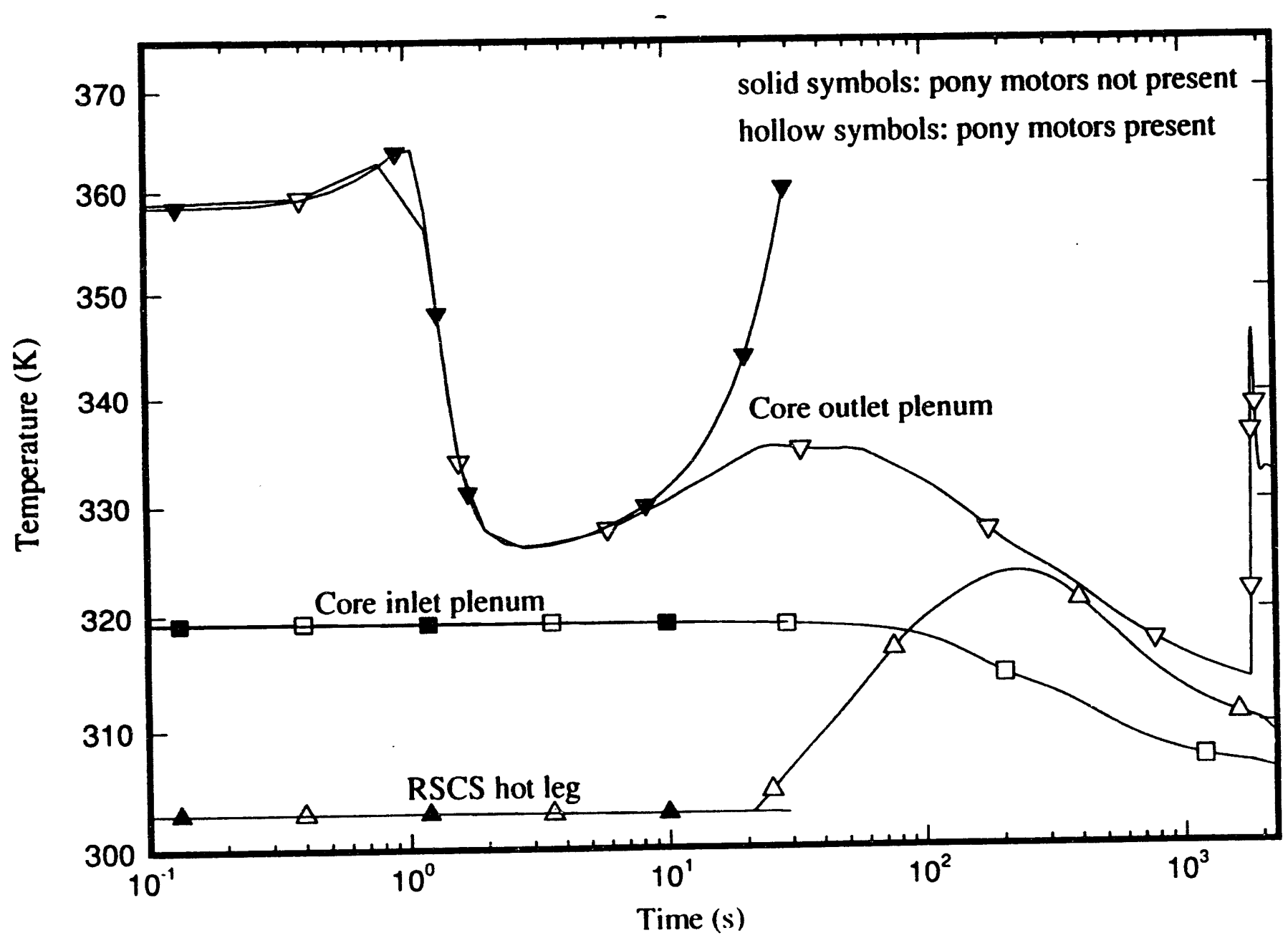

Fig. 5. Temperature vs time. (RSCS = reactor secondary cooling system.) 


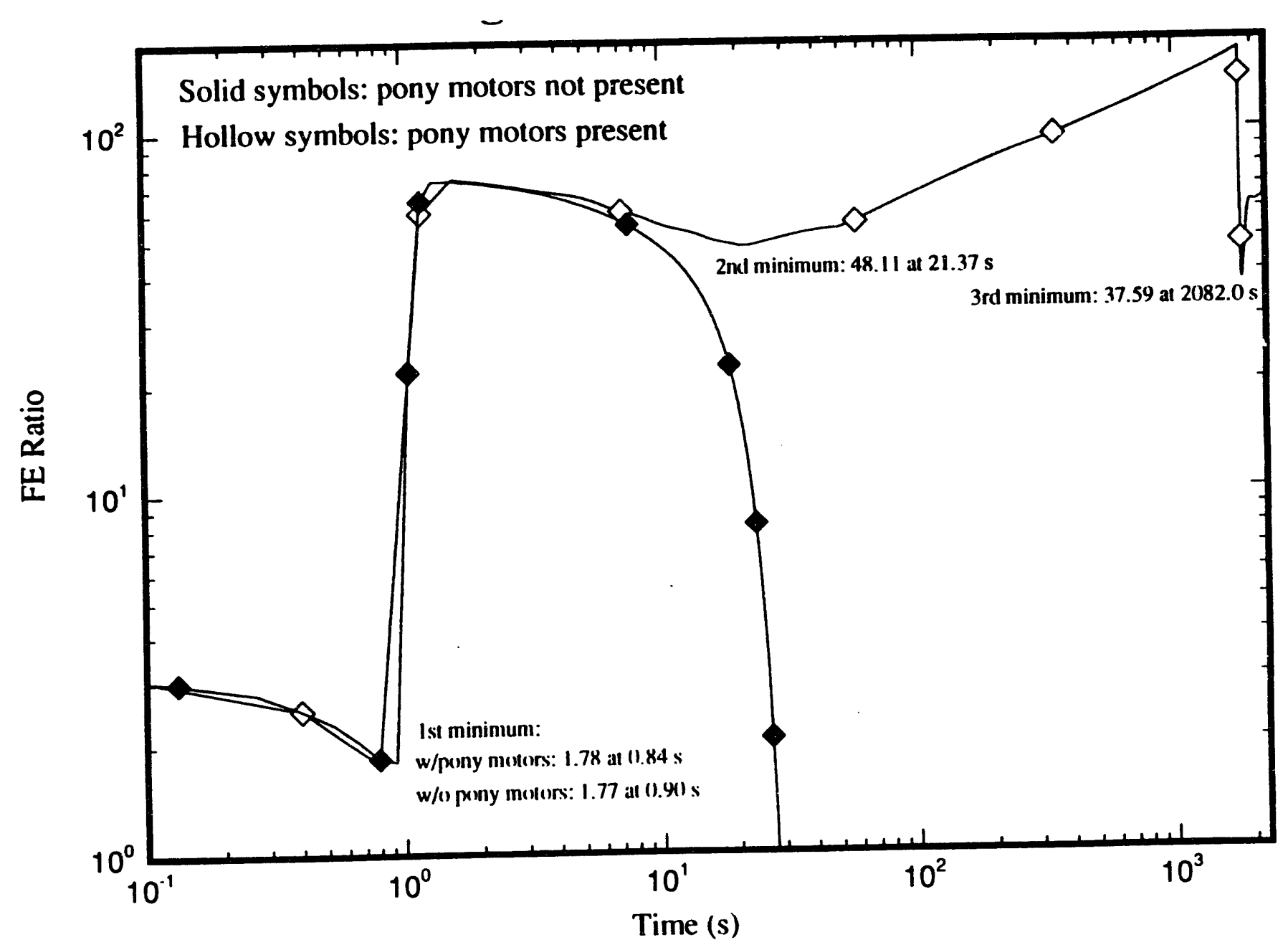

Fig 6. Fow excursion vs time. 


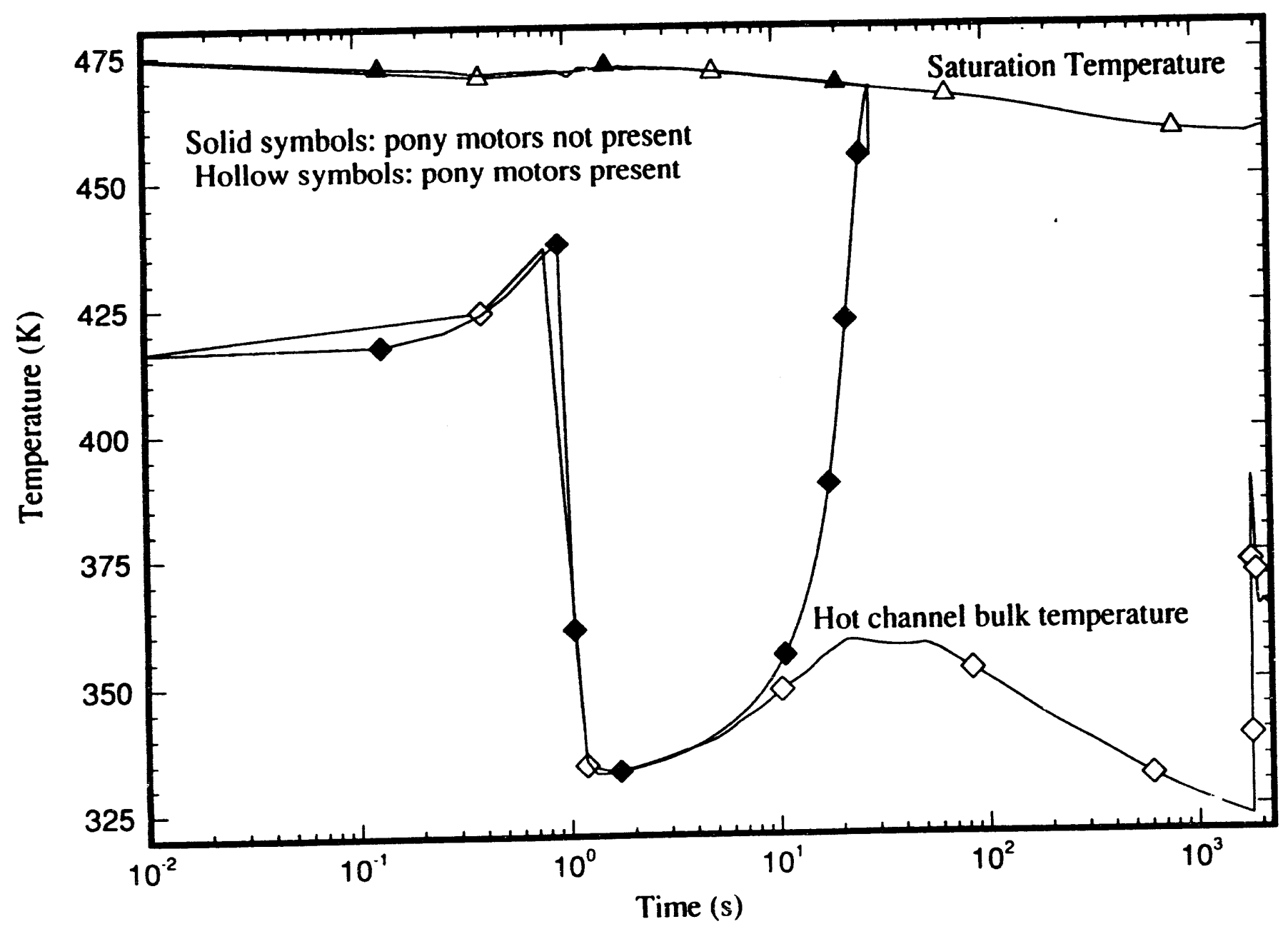

Fig. 7. Core subcooling. 


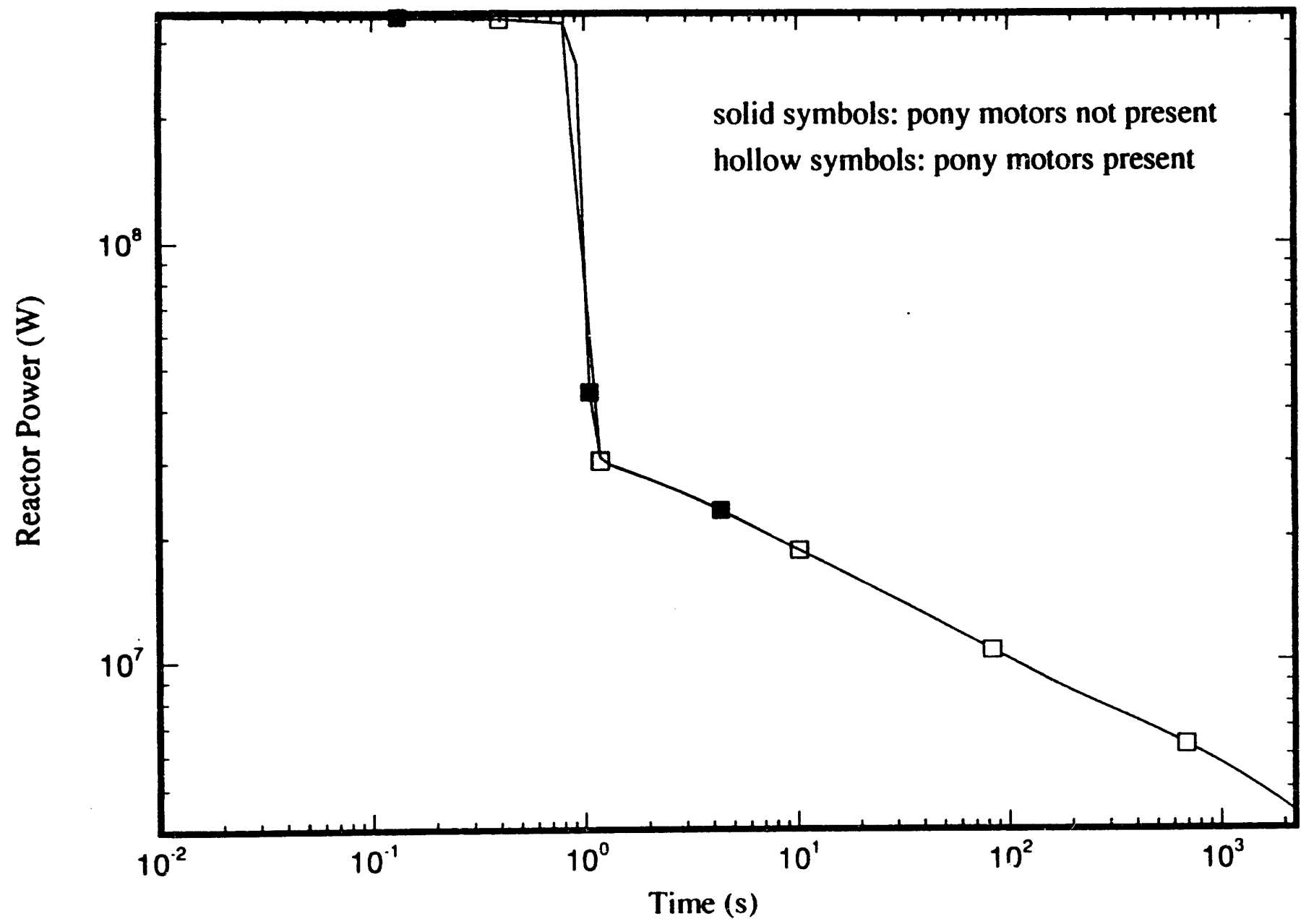

Fig. 8. Reactor power vs time. 
The pumps in the three active secondary coolant loops are also coasting down to zero during this time. Flow through the secondary is decreasing as well, though not as quickly as pump velocity; as in the primary, the inertia of the flow prevents a sudden, precipitous drop. The loss of the pump head causes the pressure here to decrease as well-by $1.24 \mathrm{~s}$, the pressure at the pump outlet has fallen to $20 \%$ below nominal (Fig. 3). This pressure drop triggers the valves and activates the natural circulation loop, as described above. The $20 \%$ below normal set point used here was somewhat arbitrary; exact information was not available from the SDDs.

During the following seconds, the pressure drop over the core continues to decrease as the MCPs coast down (the MCPs reach zero speed at $22.5 \mathrm{~s}$ ). By $15 \mathrm{~s}$, the pressure drop is $0.0318 \mathrm{MPa}$, and at $25 \mathrm{~s}$, it is down to $0.0172 \mathrm{MPa}$. The FE ratio, having reached a maximum at $2.0 \mathrm{~s}$, begins to fall off rapidly. This fall occurs because the effect of decreasing core flow velocity on the $\mathrm{FE}$ ratio predominates over the effect of the declining decay heat.

These conditions lead to failure unless natural circulation 'sith adequate mass flow can be established in the RPCS before the FE ratio drops below one. Since such natural circulation does not develop, however, the simulation fails at $28.9 \mathrm{~s}$ because of core overheating in the hot channel. Wall temperatures in the core, which had dropped below the saturation temperature $\left(T_{m a t}\right)$ just after reactor scram, once again rose above $T_{m a t}$ at $23 \mathrm{~s}$, as indicated by RELAP5 critical heat flux (CHF) calculations. Also, subcooling decreased rapidly to zero; by $28.5 \mathrm{~s}$, significant voiding was evident in the hot channel.

The reactor could not survive this case because adequate natural circulation did not develop upon MCP coastdown; the core flow of $48.1 \mathrm{~kg} / \mathrm{s}$ at the time of failure was not sufficient to remove the decay heat from the core. Natural circulation did not have an opportunity to develop before the FE criteria exceedence because of (1) relatively higher system depressurization than in the case with a battery-powered pony motor (to be described below) and (2) insufficient buoyancy forces resulting from the small temperature rise through the core to initiate natural circulation by itself.

The flow in the secondary loop (Fig. 4) during this time was also coasting down and reached $128 \mathrm{~kg} / \mathrm{s}$ at the time the FE limit was exceeded. At this time the secondary coolant pump had not completely coasted down-it was still rotating at $2.5 \%$ of normal speed. Pressure at the pump outlet fell from 0.273 to $0.172 \mathrm{MPa}$ during the first $5 \mathrm{~s}$ of the transient, then remained approximately constant. Since the RSCS is not connected to the letdown system, water inventory was conserved, and no additional depressurization was seen. In fact, at the time of failure, the combined heat transfer from the RPCS to the RSCS in each of the three main heat exchangers (MHXs) stood at $16.1 \mathrm{MW}$; decay heat was only $14.1 \mathrm{MW}$ total, so the average primary coolant temperature was declining. It could not be determined whether natural circulation in the secondary was developing. Even at the time of failure, most of the flow still passed through the pump rather than the natural circulation leg.

\subsection{CASE B: WTTH BATTERIES}

After it became apparent that the FE limit was exceeded, it was decided to run a case that differed from the first in one respect-rather than coasting down to zero, the MCPs would be maintained at $10 \%$ of their nominal speed by battery-powered pony motors. This transient begins at $0 \mathrm{~s}$ (see Table 2 for a summary of the transient) and, for the first 
Table 2. Events timeline-station blackout with pony motors

\begin{tabular}{|c|c|}
\hline $\begin{array}{c}\text { Time } \\
(\mathbf{s})\end{array}$ & Event \\
\hline 0.00 & $\begin{array}{l}\text { Beginning of transient; loss of external power; coastdown of primary, secondary } \\
\text { and makeup pumps begins }\end{array}$ \\
\hline 0.24 & Monte Carlo pumps at $50 \%$ speed \\
\hline 0.61 & $\begin{array}{l}\text { Power/flow ratio set point of } 1.2 \text { (the nominal value of } 1.15+5 \% \text { for } \\
\text { uncertainties and set point drift) exceeded; reactor scram signal sent }\end{array}$ \\
\hline 0.66 & T. akeup flow reaches zero upon check valve closure \\
\hline 0.81 & Control rod insertion (scram stroke) begins \\
\hline 0.82 & Net accumulator outflow begins \\
\hline 0.84 & Hot stripe bulk temperature reaches maximum of $436 \mathrm{~K}$; subcooling $=33 \mathrm{~K}$ \\
\hline 0.84 & $\begin{array}{l}\text { First flow excursion minimum, } 1.78 \text {, reached because of decreasing core flow } \\
\text { and initial depressurization }\end{array}$ \\
\hline 1.24 & $\begin{array}{l}\text { Pressure at secondary pump outlet drops to set point (assumed to be } 20 \% \text { below } \\
\text { nominal); natural circulation valves in secondary loops open and forced } \\
\text { convection valve closes }\end{array}$ \\
\hline 2 & Accumulator outflow peaks at $15 \mathrm{~kg} / \mathrm{s}$ per accumulator \\
\hline 2.79 & Temperature at core outlet reaches minimum of $345.6 \mathrm{~K}$ \\
\hline 5.58 & Pressure at hot leg riser outlet in primary reaches set point ( $15 \%$ below nominal) \\
\hline 13.00 & Letdown system isolated by valves \\
\hline 20.50 & Critical heat flux ratio minimum of 48 reached \\
\hline 21.37 & $\begin{array}{l}\text { Second flow excursion minimum, } 48.11 \text {, reached because of Monte Carlo pump } \\
\text { coastdown }\end{array}$ \\
\hline 33 & Secondary coolant pumps coast down to zero \\
\hline 39 & Makeup pump coasts down to zero \\
\hline 42.21 & Secondary flow reaches minimum of $44 \mathrm{~kg} / \mathrm{s}$ \\
\hline 100 & $\begin{array}{l}\text { Monte Carlo pumps reach new steady state with pony motors providing } 10 \% \text { of } \\
\text { nominal speed }\end{array}$ \\
\hline 194 & Secondary flow reaches maximum of $84 \mathrm{~kg} / \mathrm{s}$ \\
\hline 230 & Total accumulator injection falls below $1 \mathrm{~kg} / \mathrm{s}$ \\
\hline 1800.00 & Pony motor batteries on reactor primary cooling system pumps expire \\
\hline 1801.00 & Monte Carlo pump coastdown completed \\
\hline 1830.90 & Core flow minimum of $26.55 \mathrm{~kg} / \mathrm{s}$ reached \\
\hline 1832.00 & $\begin{array}{l}\text { Third flow excursion minimum, } 37.59 \text {, reached because of the transition from } \\
\text { forced convection to natural circulation in the reactor primary cooling system }\end{array}$ \\
\hline 1865 & Temperature at core outlet reaches maximum of $345.6 \mathrm{~K}$; subcooling $=70 \mathrm{~K}$ \\
\hline 2020 & $\begin{array}{l}\text { Onset of net heat transfer from the emergency heat exchanger to the reactor } \\
\text { primary sooling system }\end{array}$ \\
\hline 2250.00 & End of calculations \\
\hline
\end{tabular}


few seconds, proceeds very similarly to the first case. This similarity is expected because the pumps coast down similarly for the first $10 \mathrm{~s}$; in this trial, however, MCP velocity is maintained at least $10 \%$ after $10 \mathrm{~s}$, whereas it had previously been allowed to fall to zero. Differences may be noted by $15 \mathrm{~s}$ into the transient; core flow without the pony motors is $174.4 \mathrm{~kg} / \mathrm{s}$, while with the pony motors it is $275.5 \mathrm{~kg} / \mathrm{s}$. Also, the pressure drop over the core remains at $0.0408 \mathrm{MPa}$ at $25 \mathrm{~s}$ into the transient, whereas in the previous case it had fallen to $0.0172 \mathrm{MPa}$. Although the wall temperature in this case also rises above $T_{\text {eat }}$ just after $20 \mathrm{~s}$ into the transient, the FE ratio only drops to 48.11 from its maximum of 75 . This occurs at $271.37 \mathrm{~s}$ and is considered the second FE minimum. After this point, as core flow arrives at a new steady state, it ceases to decrease at a greater rate than decay heat. The pump head, combined with the buoyancy effect from the temperature rise over the core, is sufficient to maintain core flow at a steady $170 \mathrm{~kg} / \mathrm{s}$, while the FE ratio rises over the next several hundred seconds as a result of the declining decay heat.

Natural circulation has developed in the secondary loop $-250 \mathrm{~s}$ into the transient. This natural circulation is the result of the thermal siphon effect created by the presence of the large storage basins. The presence of less dense, heated water in the hot leg draws cooler water from the bottom of the basin into the cold leg. This water is pulled into the heat exchanger, where it is heated and then deposited through the hot leg into the top of the basin. The coolest water will thus always be located at the bottom of the basin, and the $17,600 \mathrm{~m}^{3}$ volume of the basin ensures that there will be a large temperature difference between the bottom and the top for an extended period of time. The significance of this temperature gradient may be gauged by examining when the natural circulation mass flow in the RSCS peaks. This peak in mass flow occurs at $194 \mathrm{~s}$, when the flow reaches $84 \mathrm{~kg} / \mathrm{s}$ per loop. At this time, the temperature difference between the cold leg and the hot leg in the RSCS is also at its largest-22 K. An important factor in determining the effectiveness of natural circulation is the depth of the pool. If the pool is too deep, coolant water must overcome a large static head to rise through the heat exchanger from the cold leg elevation to the elevation of the top of the pool. If, however, the pool is too shallow, the average temperature at the bottom of the pool will rise quickly as a result of conduction with the warmer water at the top. The current elevation difference between the cold leg outlet and the hot leg inlet in the pool is $7.92 \mathrm{~m}(26 \mathrm{ft})$, which produces a steady-state flow in each loop of $\sim 50 \mathrm{~kg} / \mathrm{s}$.

This flow is more than adequate to cool the primary; in fact, overcooling appears to be taking place. Water temperature in the cold leg of the RPCS drops from its pre-accident value of 319.5 to $307.3 \mathrm{~K}$ by $1250 \mathrm{~s}$. This temperature drop indicates that, over time, the RSCS has absorbed more heat than is being produced in the core. It was not even expected, under natural circulation conditions, that the RSCS would be capable of removing all the decay heat produced by the core. It was expected that the RSCS would remove some of the heat, and the emergency heat exchanger (EHX) would remove the rest.

The EHX is located in series downstream of the MHX outlet in the cold leg of the RPCS and is designed to create self-sustaining natural circulation. The water passing through the primary side, being warmer than the water in the reactor pool, which provides water for the secondary side of the EHX, heats the water in the EHX secondary. The warm, less dense water in the EHX secondary tends to move upward toward the top of the pool, pulling denser, colder water into the EHX. This upward movement cools the RPCS, sustaining natural circulation on both the primary and the secondary sides of the EHX. 
Such natural circulation never actually develops in the above-mentioned case because so much heat is removed in the MHX that the RPCS cold leg temperature is virtually the same as ihe reactor pool temperature. Because there is almost no temperature difference between the primary and the secondary sides in the EHX, very little heat transfer takes plice, and flow in the secondary side cannot be sustained-it diminishes from $30.8 \mathrm{~kg} / \mathrm{s}$ at $0 \mathrm{~s}$ to $10.2 \mathrm{~kg} / \mathrm{s}$ at $1250 \mathrm{~s}$. Heat transfer likewise drops, from $0.644 \mathrm{MW}$ at $0 \mathrm{~s}$ to $0.023 \mathrm{MW}$ at $1250 \mathrm{~s}$. These results call into question the need for the EHX. If the RSCS removes the decay heat so effectively, then perhaps the EHX could be omitted. This removal would be feasible if it could be stated with confidence that flow in the RSCS would never be interrupted. It is possible that the accidental closure of a valve $O$ a rupture somewhere in the RSCS piping could occur and disable one or more RSCS loops, in which case, the EHX would most likely be quite necessary, as they would be an important mechanism for heat removal from the RPCS.

The pony motors on the primary coolant pumps are battery powered. These batteries have a life of $30 \mathrm{~min}$; at $1800 \mathrm{~s}$, therefore, the batteries expire and the MCPs coast down, over an assumed period of $1 \mathrm{~s}$, to zero. The loss of the remaining pump head causes the pressure drop over the lower core to fall from 0.032 to $0.015 \mathrm{MPa}$ and the core flow to decrease from 170 to a minimum of $26.55 \mathrm{~kg} / \mathrm{s}$ at $1830.9 \mathrm{~s}$. A lower core flow causes an increase in core outlet temperature-it peaks at $345.6 \mathrm{~K}$ at $1865 \mathrm{~s}$. Subcooling has dropped from a maximum of $136 \mathrm{~K}$ just before the expiration of the batteries to $70 \mathrm{~K}$ at $1865 \mathrm{~s}$. These conditions cause the FE ratio to drop from a maximum of 162.74 at $1800 \mathrm{~s}$ to 37.59 at $1832.0 \mathrm{~s}$. The conditions that bring about the third FE minimum are similar to those that caused the first-decreasing core velocity coupled with an essentially constant heat flux. The core survives this minimum easily, however; by $1925 \mathrm{~s}$ the FE ratio has climbed to 57 and continues to rise gradually. Here it may be seen that natural circulation does develop. At $1950 \mathrm{~s}$ core flow has risen to $50 \mathrm{~kg} / \mathrm{s}$, and it remains at that value. The very loss of flow that caused the increase in core outlet temperature causes natural circulation to form, for it is the thermal siphon effect of increased temperature difference over the core that causes flow to increase once again. In the previous case, when no pony motors were used, the FE limit was exceeded because of the extended period of time, perhaps on the order of $100 \mathrm{~s}$, that is required for natural circulation to fully develop. Only later in the transient, after the decay heat output of the reactor has decreased significantly, is the thermal limit not exceeded during this transition. 


\section{CONCLUSIONS}

The ANSR with the CSAR reference core can survive a station blackout without exceeding the FE thermal limit if the pony motors on the MCPs operate. This ability is the result of the inability of the reactor to survive the second FE minimum. The transition from forced convection to natural circulation causes flow in the primary to decrease below the level that is required to remove adequate heat from the core; if this transition takes place $30 \mathrm{~min}$ after reactor scram instead of immediately afterward, however, the reactor can survive because the lower level of decay heat is absorbed by the RPCS. A similar transient was run, subject to the same input conditions but including an updated core fuel grading. ${ }^{10}$ This model could survive even the case without the pony motors; it appeared that this is so because steady-state, pretransient subcooling in the new core model is significantly greater.

Natural circulation dcvelops in the RSCS because of the thermal siphon effect created by the coolant basins and the temperature differential over the MHX - a mass flow of $50 \mathrm{~kg} / \mathrm{s}$ was calculated in the secondary under natural circulation conditions. The new RSCS model can therefore be used in the future whenever a detailed, physically accurate simulation of the secondary is iecessary. Also, the previous model assumes a linear coastdown of flow in the RSCS from 100 to $5 \%$ in 10 s; the RELAP5 model of the RSCS predicts coastdown from 100 to a minimum of $2.8 \%$ after $40 \mathrm{~s}$, then a gradual convergence to a steady-state value of $3.2 \%$. The impact of this other difference is marginal; since significant overcooling takes place in the MHX in both models, failure cannot be attributed to a lack of heat removal in one model as compared to the other. In fact, the new RSCS model can be expected to perform its function of removing the proper amount of heat from the primary under forced convection and natural circulation conditions. 


\section{REFERENCES}

1. M. Siman-Tov et al., "Thermal-Hydraulic Correlations for the Advanced Neutron Source Reactor Fuel Element Design and Analysis," Proc. American Society of Meshanical Engineers Winter Mtg., Atlanta, 1991.

2. ANS Conceptual Safety Analysis Report, ORNL/ANS-INT-33/V4, Martin Marietta Energy Systems, Inc., Oak Ridge National Laboratory, June 1991.

3. K. E. Carlson et al., RELAP5/MOD3 Code Manual, NUREG/CR-5535, EGG-2596, Vols. 1, 2, and 3, EG\&G Idaho, Inc., Idaho Falls, Idaho, June 1990.

4. C. D. Fletcher et al., "Conceptual Design Station Blackout and Loss-of-Flow Accident Analysis for the Advanced Neutron Source Reactor," Nucl. Technol., in press.

5. N. C. J. Chen et al., "Conceptual Design Loss-of-Coolant Accident Analysis for the Advanced Neutron Source Reactor," Nucl. Technol., in press.

6. System Design Description SDD-61: Reactor Water Systems, ORNL/ANS/INT-26/R0, Martin Marietta Energy Systems, Inc., Oak Ridge National Laboratory, June 1992.

7. System Design Description SDD-64: Plant Water Systems, ORNL/ANS/INT-26/R0, Martin Marietta Energy Systems, Inc., Oak Ridge National Laboratory, June 1992.

8. Drawings, ORNL/ANS/INT-26/S10/R0, Martin Marietta Energy Systems, Inc., Oak Ridge National Laboratory, June 1992.

9. J. Costa, "Measurement of the Momentum Pressure Drop and Study of the Appearance of Vapor and Change in the Void Fraction in Subcooled Boiling at Low Pressure," presented at European Group Double-Phase Meeting, Winfrith, U.K. 1967; English translation, ORNL/TR-90/21, Martin Marietta Energy Systems, Inc., Oak Ridge National Laboratory.

10. N. C. J. Chen, Martin Marietta Energy Systems, Inc., Oak Ridge National Laboratory, personal communication to E. A. Schneider, Cornell University, Ithaca, New York, 1993. 
Appendix A. REFLECTOR VESSEL COOLING SYSTEM 


\section{Appendix A. REFLECTOR VESSELL COOLING SYSTEM}

The reactor vessel cooling system (RVCS), like the primary and secondary systems, consists of four identical loops. Three of these loops have been comprehensively modeled, while the parts of the standby loop that are isolated by valves have been omitted for simplicity. For clarity, the nodalization diagram (Fig. 9) displays only one of the loops. The reflector vessel, represented by pipe 101, has a volume of $40 \mathrm{~m}^{3}$. It surrounds the core pressure boundary tube (CPBT)-under normal operating conditions, $17.5 \mathrm{MW}$ of heat is transferred from the CPBT to the reflector vessel. From the reflector vessel, flow progresses through the hot let riser (pipe 103) and is distributed to the three active loops. Check valves 107, 207, and 307 are open under normal conditions. Flow then passes through the pump (pumps 109, 209, and 309) and then the heat exchanger. Multiple junctions 120,220 , and 320 represent the inlet to the letdown channel. Only $1 \mathrm{~kg} / \mathrm{s}$ of water flows through the letdown/makeup system; its primary function in this model is to control the pressure of the system. This control is accomplished by fixing the pressure at the top of the letdown tank (branch 116) at $135 \mathrm{kPa}$ by use of a time-dependent volume (TDV 160). The makeup from the letdown tank is then injected through $0.0381-\mathrm{m}$ (1.5-in.-) diam pipe into the hot leg distribution area (branch 105). Most of the flow leaving the main heat exchanger, however, enters the cold leg (pipes 121, 221, and 321) and returns to the bottom of the reflector pool. Steady-state operation of this model under nominal conditions (17.5 MW of heat transferred and a flow rate of $240 \mathrm{~kg} / \mathrm{s}$ in the reflector pool) has been achieved, and the model is to be integrated into the currently existing RELAP5 simulation of RPCS and RSCS. 


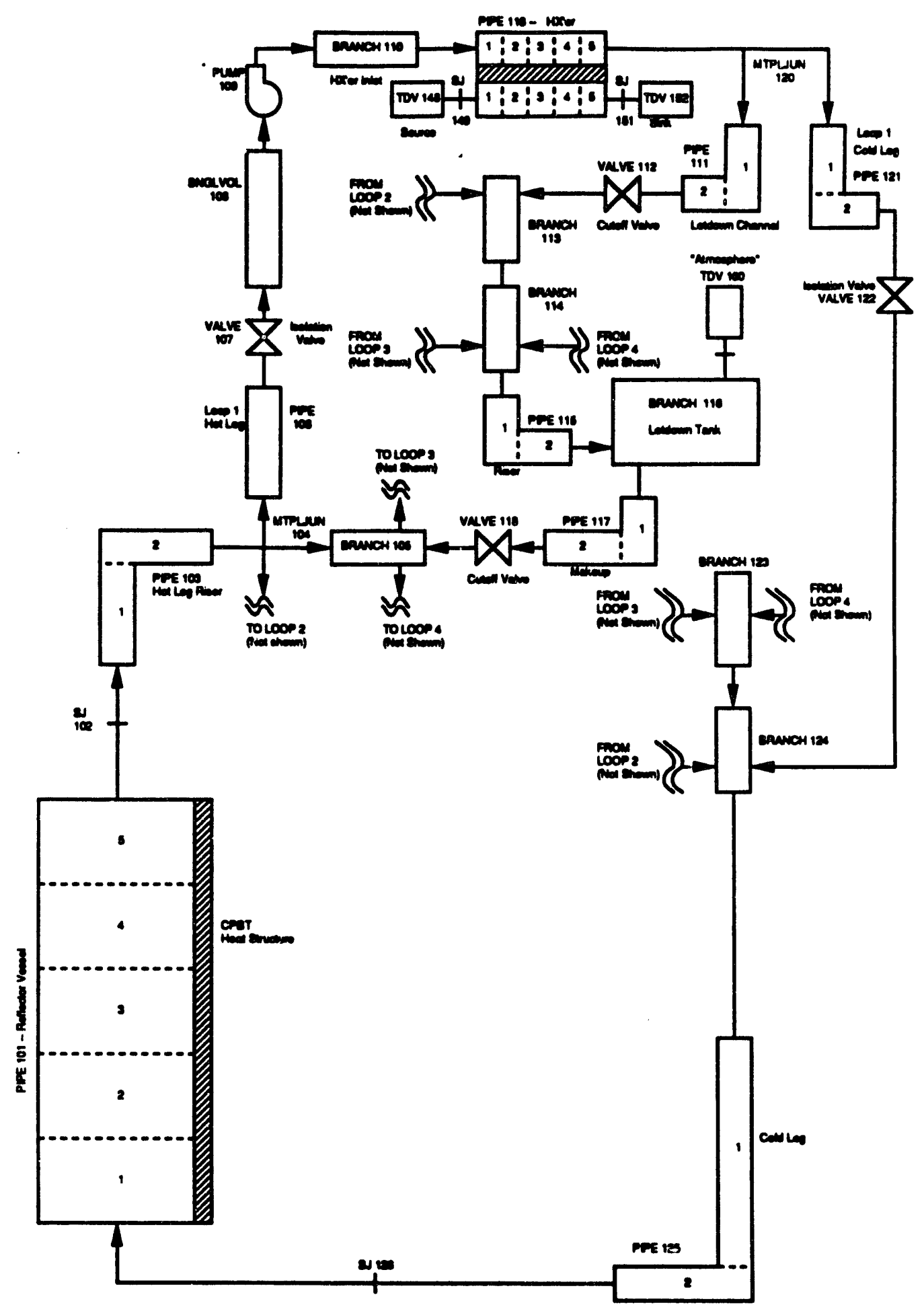

Fig. 9. Advanced Neutron Source reactor reflector vessel cooling system-node diagram. 
Appendix B. PROPORTIONAL-INTEGRAL-DIFFERENTIAL CONTROL 
The most challenging aspect of obtaining a steady-state for the RSCS was to properly adjust the proportional-integral-differential (PID) controllers. In the RSCS model, PID control was used to adjust both the cooling tower flow and the pump speed. Cooling tower flow was adjusted so that the temperature in the cold leg remained at its proper value of $303 \mathrm{~K}$, and pump speed was adjusted so that the proper mass flow to transfer the desired amount of heat from the RPCS was obtained. PID control was necessary so that constant adjustments to the desired quantity are made during the simulation, keeping all parameters within nominal operating range. For example, the following equations were used to control the pump speed:

$$
\begin{gathered}
\Delta T=T_{\text {holleg }}-T_{\text {sappoint }}, \\
\text { intgr }=\int_{0}^{1} \Delta T d t, \\
\text { deriv }=\frac{d \Delta T}{d t}, \\
\Delta \text { speed }=K_{1}(\Delta T)+K_{2}(\text { Intgr })+K_{3}(\text { Deriv })+\text { bias }, \\
\text { speed }=\text { speed }+\Delta \text { speed } ;
\end{gathered}
$$

where

$T_{\text {hot }}=$ temperature in hot leg of RPCS (K),

$T_{\text {setpoint }}=$ desired temperature in RPCS hot leg $(=319.5 \mathrm{~K})$,

speed $=$ RSCS pump speed,

$K_{1}, K_{2}, K_{3}$, bias = constants to be determined.

The primary difficulty involved determining the values for the constants $K_{1}, K_{2}, K_{3}$, and bias. Several trials were required to obtain values that caused the pump speed to converge within a reasonable time period; if the proportional term, for example, was given too much weight, the pump speed would oscillate dramatically around the correct value and never settle in to a steady state. 


\section{Internal Distribution}

1. B. R. Appleton

2. N. C. J. Chen

3. W. G. Craddick

4. M. L. Gildner

5. R. M. Harrington

6. J. B. Hayter

7. R. O. Hussung

8-11. R. L. Johnson

12-16. K. K. Jones

17. D. L. Moses

18. D. L. Selby

19. P. B. Thompson

20. G. L. Yoder

21. ORNL Parent Office

22-23. Central Research Library

24. Y-12 Technical Library, Document Reference Section

25-26. Lab Records

27. Lab Records (RC)

\section{External Distribution}

28-32. Erich A. Schneider, Cornell University, Ithaca, NY 14853

33-34. Office of Scientific and Technical Information, P.O. Box 62, Oak Ridge, TN 37831 

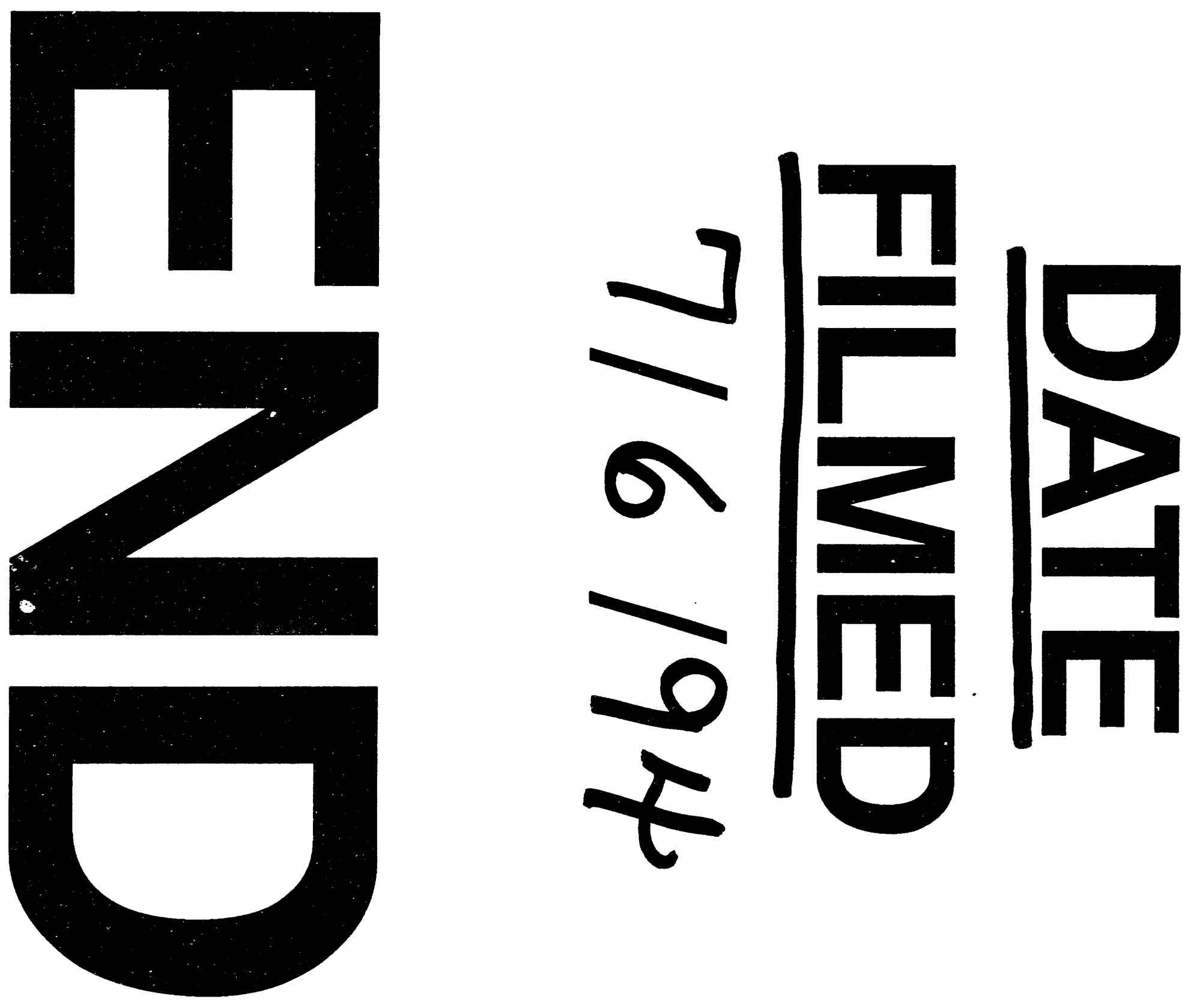
